\title{
ECONOMIC DEVELOPMENT OF EASTERN EUROPEAN COUNTRIES (ON THE EXAMPLE OF UKRAINE): REGIONAL ASPECT
}

\author{
Kseniia Sieriebriak', Oleksandra Melnykova²
}

\begin{abstract}
Research background. Modern trends in world politics and international relations dictate new schemes for establishing links between regions and encourage states to constantly improve them. One such form is economic cooperation between regions, whose development strategies are gradually being introduced in countries around the world. Since Ukraine signed an association agreement with the European Union, in most economic and legal issues it relies on the experience of the European countries. In addition, worthy of attention is the analysis of the current state of the regional development in Ukraine and on its basis the formation of the basic principles for interregional cooperation. Such experience and identifying main economic trends in the formation of economic cooperation between different regions can help Ukraine to introduce this process in practical terms and possibly avoid the most popular problems in this area. Purpose of the article. The provisions of the article provide a systematic estimation of the regional development of Ukraine based on the calculation of the Spearman coefficient from 2006 to 2016. On the basis of these calculations, the main preconditions for the economic development of interregional cooperation are analysed and the basic principles of such cooperation for the regions of Ukraine are formed. Methodology/methods. This work is based on the generalization of the official methodological information of the following Ukrainian regions that are the most interested for the economic foundations of the interregional development. Ukraine has a new decentralization reform for the regions, which will be able to give impetus to the economic development and increase the effectiveness of the interregional ties. Nevertheless, since this process is quite new for our country, it is critically important to study foreign experience in this field. In the future, as a result of such studies, it would be possible to develop economic and legal mechanisms for introducing the best world practices in the Ukrainian legal field. Value/originality. The provisions of the article solve an important theoretical and practical task - firstly for Ukraine - contribute to the formation of the interregional cooperation institution since by this time there is no unanimous opinion on the legislative level or on the scientific one. It seems possible, through such studies, to create the real mechanisms for the regional development in Ukraine and their cooperation with each other. Most Ukrainian and world economists view the development of the regions as such in themselves, no one examines it through the prism of economic development of interregional cooperation. We support and use this approach, because it is very important, as it provides an opportunity to comprehensively analyse the current state of the meso-level in Ukraine. For the first time in Ukraine, the results of the formation development at the regional level in the context of interregional cooperation are presented in the detailed description that could give the opportunity to Ukrainian economists for the next step in this scientific field. Practical implications. The results of this article will form the basis for the assistance to various regions in Ukraine in the matter of strategic planning and their cooperation since no clear and detailed actions for them have yet been recorded. In addition, this work is relevant for representatives of state authorities and scientists who deal with issues of the regional economy because no one in Ukraine has ever considered these issues in the context of interregional cooperation.
\end{abstract}

Key words: regional economy development, regions, interregional cooperation.

JEL Classification: P25, O10, R11

\footnotetext{
Corresponding author:

${ }^{1}$ Volodymyr Dahl East-Ukrainian National University, Ukraine.

E-mail: belousova_2014@ukr.net

${ }^{2}$ Kyiv National Economic University named after Vadym Hetman, Ukraine.

E-mail: alx.melnikova@gmail.com
} 


\section{Introduction}

One of the priority directions for implementing the state policy in many countries of the world is to ensure sustainable regional development; the ways of achieving are the same in different countries of the world. This concern the solution of such issues as overcoming regional disproportions, ensuring effective development of the productive forces, rational using of regional resources etc. Considering Ukraine's desire to become a full-fledged member of the European Union in accordance with the signed association document and to become a strong and competitive subject of the world arena, it is important to seek new sources and forms of development of the state regional policy. In such conditions, the interdependence of ties between regions is becoming increasingly important, based on their cooperation in various fields of activity (infrastructure, information, social services, etc.) for the overall improvement of the people's welfare and the development of regions and the country as a whole. Given this, the economic cooperation between regions is one of the main forms of the modern development of the regional policy in many countries of the world, including Ukraine. In contrast to the process of competition, the economic cooperation between regions in the strategic dimension is able to provide effective complementation of resources, expand opportunities for building up the internal potential of each region, and achieve synergies from their interaction. It could consolidate the nationwide socio-economic development.

In addition, the modern trends in world politics and international relations make the old schemes of establishing economic ties between regions ineffective and this situation encourages states to continually improve them. Therefore, a comprehensive approach to the research of the development process of the economic cooperation between regions will make it possible to present a picture of the trends in the development of interregional ties of some countries in the world. In addition, it could identify the problems of this type of cooperation with a view to working out the most effective solutions for improving this process in Ukraine.

\section{Research methodology}

The research is based on official statistics of Ukraine, based on the tendency of the Ukrainian regional development for the period from 2006 to 2016. The methodological basis of the regional economic cooperation development is the systemic and situational approaches. According to the system approach, the regional development could be regarded as a system consisting of certain interrelated elements that ensure its life activity, and elements of a larger system, which functioning and development are determined by economic laws and patterns characteristic. According to the situational approach, regional development is a complex socio-economic system, characterized by a number of its unique features.

Ukraine has a new decentralization reform for the regions, which will be able to give impetus to the economic development and increase the effectiveness of the interregional ties. However, since this process is quite new for our country, it is critically important to study foreign experience in this field. In the future, as a result of such studies, it will be possible to develop economic and legal mechanisms for introducing the best world practices in the Ukrainian legal field.

\section{The current assessment of the regional development in Ukraine}

The prerequisite for the economic ties development within any country in the world is the identification of trends in the overall economic development of its regions, allows many stakeholder groups (scientists, practitioners, society as a whole) to identify the problems of the relevant development area and look for ways to solve them. Ukraine is no exception in this case since, for an adequate study of the basics for interregional cooperation, it is necessary to understand the current state of the country, in particular, the trends and the effectiveness of its regions' development.

Such analysis and assessment are possible using a large arsenal of methods, among which the most accurate are the economic and mathematical methods because they allow us to explore the possibility of carrying out an assessment in dynamics. Thus, it is proposed to assess the tendentiousness and effectiveness of economic development in the Ukrainian regions, using the Spearman rank correlation coefficient for the period of available statistical data, namely from 2006 to 2016.

The use of the Spearman rank correlation coefficient for assessing the tendencies in the economic development of the regions in Ukraine provides for the determination of the rates of change $\left(T_{i}\right)$ of indicators characterizing the development of the economy through efficient investments $\left(\mathrm{T}_{\mathrm{GRP}}>\mathrm{T}_{\mathrm{CI}}\right)$, which ensure the outstripping growth of industrial $\left(\mathrm{T}_{\mathrm{VSIP}}\right)$ and agricultural $\left(\mathrm{T}_{\mathrm{AP}}\right)$, as well as the cost of innovative products $\left(\mathrm{T}_{\mathrm{VIP}}\right)$, so there is an accelerated growth of value added $\left(\mathrm{T}_{\mathrm{GRP}}\right)$. In addition, this affects the improvement on the structure of the population consumption $\left(\mathrm{T}_{\mathrm{IP}}>\mathrm{T}_{\mathrm{RTE}}\right)$, the growth of the total labour productivity $\left(\mathrm{T}_{\mathrm{GRP}}>\mathrm{T}_{\mathrm{NP}}\right)$, the reduction of the technogenic load on the environment $\left(T_{V S I P}>T_{V R U}\right)$, the decrease in the unemployment rate $\left(\mathrm{T}_{\mathrm{NP}}>\mathrm{T}_{\mathrm{UP}}\right)$.

The proximity of the actual dynamics to the normative series, which has to be not downward ( $>1$ or $>100 \%$ ), testify to the presence of development by socioeconomic and innovation factors (1):

$\mathrm{T}_{\mathrm{GRP}}>\mathrm{T}_{\mathrm{IP}}>\mathrm{T}_{\mathrm{RTE}}>\mathrm{T}_{\mathrm{VIP}}>\mathrm{T}_{\mathrm{VSIP}}>\mathrm{T}_{\mathrm{AP}}>\mathrm{T}_{\mathrm{Cl}}>\mathrm{T}_{\mathrm{NP}}>\mathrm{T}_{\mathrm{VRU}}>\mathrm{T}_{\mathrm{UP}}>1$, (1)

where GRP - the gross regional product;

IP - incomes of the pop ulation; 
RTE - retail turnover of enterprises;

VIP - the volume of realized innovative products;

VSIP - the volume of sold industrial products (goods, services);

$\mathrm{AP}$ - agricultural products;

CI - capital investment;

NP - the number of the population;

VRU - the volume of fuel and energy resources/ natural gas use;

UP - an unemployed population.

To determine the degree of compliance of the normative and actual series of indicators for the development of the region's economy, the Spearman rank correlation coefficient (2) is applicable:

$$
K=1-\frac{6 \cdot S(d)^{2}}{n^{3}-n}
$$

where $S(d)^{2}$ - the squares sum of the differences in the indicators series rank;

$\mathrm{n}$ - ranks number in series.

The results of calculations using formulas 1 and 2 showed that during the analysed period, the proportions of socioeconomic development did not fully correspond to their normative dynamics series (Table 1 ). The analysis of the tendencies in the economic development of the regions in Ukraine made it possible to establish that in 2006-2007 17 regions developed more or less answering the regulatory range of the economic indicators dynamics, as evidenced by the Spearman rank correlation coefficient.

In particular, only Kyiv city, Lviv and Poltava regions had a stable and average relationship between the indicators $(0.7>\mathrm{K}>0.8)$; other regions had an unstable relationship of which: 7 regions - moderate $(0.5>\mathrm{K}>0.6)$ and 7 more regions - bright $(0.6>\mathrm{K}>0.7)$. It should also be noted that during this period, there was a slight fluctuation in the correlation coefficient between its maximum and minimum value (0.489), i.e. the range of interregional differences was the least.

In the years of 2007-2008, the situation deteriorated somewhat as the number of regions that developed according to the established ratios of economicindicators fell to 12 , or almost a third. The highest correlation rates were in Kyiv (0.758), Sumy (0.721) and Chernihiv $(0.745)$ regions. In the period under review, the spread of the correlation coefficient increased to 0.582 and the range of differences in coefficient values was observed between Kyiv (0.758) and Dnipropetrovsk (0.176) regions.

Along 2008-2009, the relationship between the strategic and actual series of dynamics for all regions was weak and unstable, as the values of the Spearman's rank correlation coefficients were lower than 0.5 , and ranged from -0.442 to 0.261 . Such low values can be explained by the fact that during this period, the regions were unable to adapt quickly to the rapid deterioration of the economic situation, a decrease in investment activity, and a decline in industrial and agricultural production caused by the global financial and economic crisis.

In subsequent years (2009-2010) in the economy of most Ukrainian regions, there was some recovery. In particular, according to the normative series of indicators dynamics, Dnipropetrovsk, Donetsk, Lviv, Khmelnytskyi regions operated by $50-60 \%$; Volyn, Ivano-Frankivsk, Kirovohrad, Luhansk, Poltava, Sumy regions - by 60-70\%; Vinnytsia, Zhytomyr, Kyiv, Mykolaiv regions - by $70-80 \%$. Only five regions could not overcome the barrier value of the rank correlation coefficient of 0.5, among them: Zaporizhzhia, Odesa, Rivne, Ternopil, and Kharkiv regions.

From 2010 to 2013, the regions developed unevenly. During this period, the economy of the regions was inefficient $(0.5>\mathrm{K})$. For the vast majority of regions, the economy was characterized by a correlation coefficient in the range of $0.5>\mathrm{K}>0.8$. Only three regions had a stable and close relationship between the normative and actual series of dynamics $(0.8>\mathrm{K}>0.9)$ - Chernivtsi (2010-2011), Zakarpattia, and Lviv regions, and also Kyiv city (2011-2012).

In 2013-2014 as a result of unpredictable political events, all regions of Ukraine, except the Rivne region, again had a weak correlation between the strategic and actual series of indicators dynamics $(\mathrm{K}<0.5)$, which caused a decline in the economic performance. By the end of 2015, only a few regions had positive shifts: Volyn, Kyiv, Odesa, Chernivtsi $(0.5>\mathrm{K}>0.6)$, Lviv, Poltava, Kharkiv regions $(0.6>\mathrm{K}>0.7)$, and in 2016 only Khmelnytskyi region had a moderate and unstable relationship between the actual and normative structure of the region's economic indicators $(0.5>\mathrm{K}>0.6)$.

In general, it should be noted that in 2006-2016, coefficients of rank correlation quickly changed their value with large amplitude, which indicates an inefficient use of the existing production potential of the regions. In addition, the rank of some indicators also often changed in a dynamic series, the reason for this was the frequent change of goals and directions of development, the absence of a system of criteria for assessing the effectiveness of economic development, through which it is possible to assess the effectiveness of the regions functioning. Based on the analysis, we will determine the economic problems of the region's development during 2006-2016 (Table 2) (Timoshin, A. S., Tiazhkorob, I. V., Davydenko, V. M. and Volkov, S. V., 2008).

Thus, the results of assessing the development trends in the economy of the Ukrainian regions based on a dynamic standard of socio-economic indicators make it possible to conclude that the biggest problem in each researching period is the decrease in the industrial production output. The reason for this negative trend is the loss of a significant number of industrial enterprises located in a territory beyond the control of the Ukrainian authorities (after the war in 2014 in the East of the country), the presence of a significant share of products 


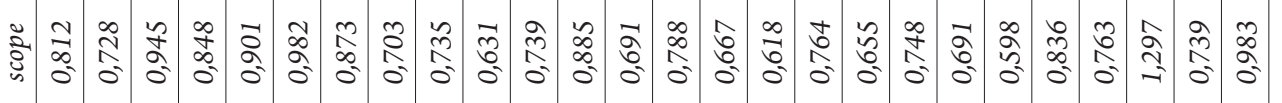

ำ

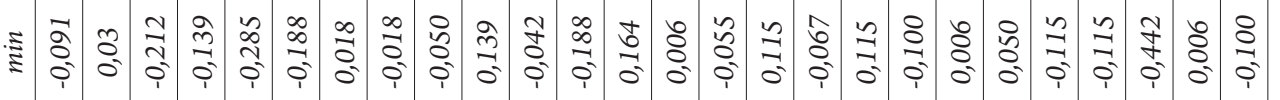

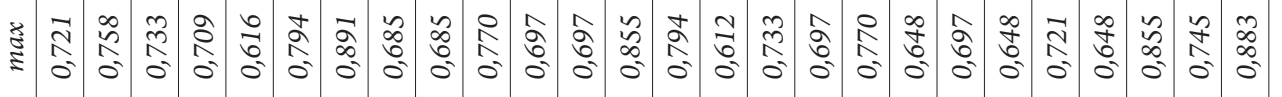

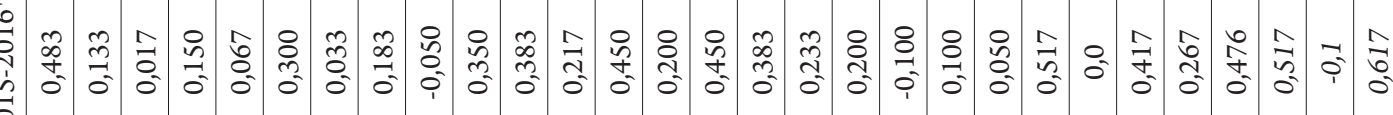

त)

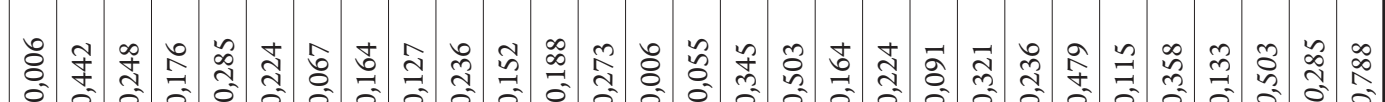

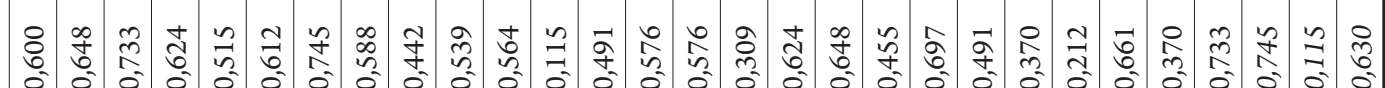

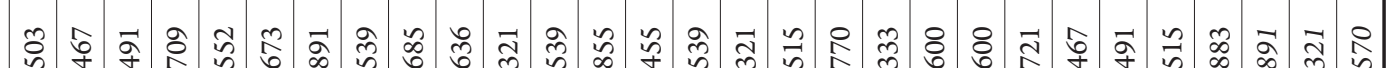

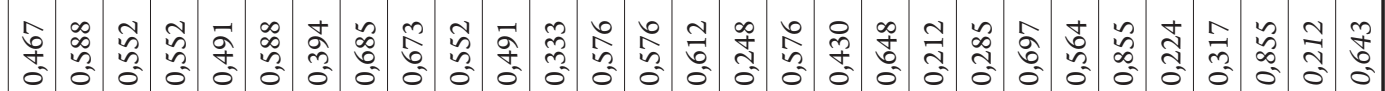

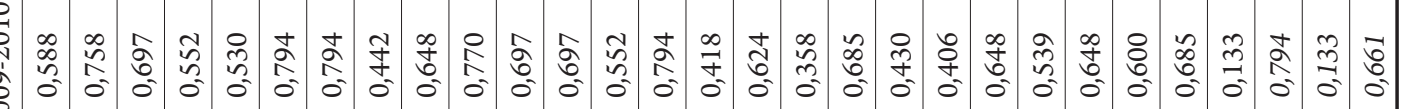

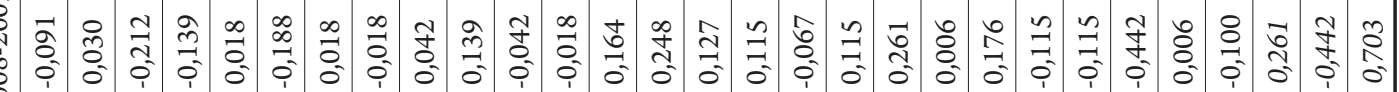

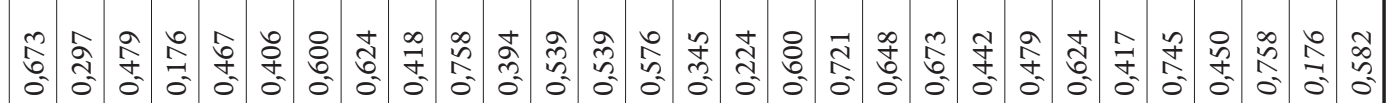

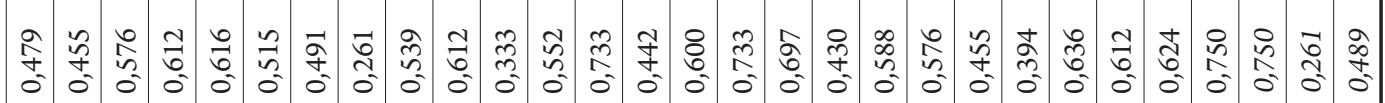


Table 2

The economic problems of the Ukrainian regions' development during 2006-2016

\begin{tabular}{|c|c|}
\hline $\begin{array}{c}\text { Order } \\
\text { of indicators }\end{array}$ & $\begin{array}{l}\text { The economic problems } \\
\text { of regional development }\end{array}$ \\
\hline \multicolumn{2}{|r|}{$2006-2007$} \\
\hline $\mathrm{T}_{\mathrm{GDP}}<\mathrm{T}_{\mathrm{IP}}$ & Decrease in the industrial production output \\
\hline $\mathrm{T}_{\mathrm{GDP}}<\mathrm{T}_{\mathrm{AP}}$ & Decrease in the agricultural production output \\
\hline $\mathrm{T}_{\mathrm{GDP}}<\mathrm{T}_{\mathrm{CI}}$ & Decrease in investment efficiency \\
\hline \multicolumn{2}{|r|}{$2007-2008$} \\
\hline $\mathrm{T}_{\mathrm{GDP}}<\mathrm{T}_{\mathrm{IP}}$ & Decrease in the industrial production output \\
\hline $\mathrm{T}_{\mathrm{GDP}}<\mathrm{T}_{\mathrm{AP}}$ & Decrease in the agricultural production output \\
\hline $\mathrm{T}_{\mathrm{VIP}}<\mathrm{T}_{\mathrm{IP}}$ & Decrease in the cost of innovative products \\
\hline $\mathrm{T}_{\mathrm{CI}}<\mathrm{T}_{\mathrm{NP}}$ & Decrease in investment volume \\
\hline $\mathrm{T}_{\mathrm{NP}}<\mathrm{T}_{\mathrm{UP}}$ & Increase in unemployment \\
\hline \multicolumn{2}{|r|}{$2008-2009$} \\
\hline $\mathrm{T}_{\mathrm{GDP}}<\mathrm{T}_{\mathrm{AP}}$ & Decrease in the agricultural production output \\
\hline $\mathrm{T}_{\mathrm{GDP}}<\mathrm{T}_{\mathrm{VSIP}}$ & Decrease in the total labour productivity \\
\hline $\mathrm{T}_{\mathrm{VSIP}}<\mathrm{T}_{\mathrm{UP}}$ & Increase in unemployment \\
\hline $\mathrm{T}_{\mathrm{CI}}<\mathrm{T}_{\mathrm{UP}}$ & Decrease in investment volume \\
\hline $\mathrm{T}_{\mathrm{VSIP}}<\mathrm{T}_{\mathrm{IP}}$ & Decrease in the cost of innovative products \\
\hline \multicolumn{2}{|r|}{$2009-2010$} \\
\hline $\mathrm{T}_{\mathrm{GDP}}<\mathrm{T}_{\mathrm{IP}}$ & Decrease in the agricultural production output \\
\hline $\mathrm{T}_{\mathrm{CI}}<\mathrm{T}_{\mathrm{UP}}$ & Decrease in investment volume \\
\hline $\mathrm{T}_{\mathrm{VSIP}}<\mathrm{T}_{\mathrm{IP}}$ & Decrease in the cost of innovative products \\
\hline \multicolumn{2}{|r|}{$2010-2011$} \\
\hline $\mathrm{T}_{\mathrm{GDP}}<\mathrm{T}_{\mathrm{IP}}$ & Decrease in the agricultural production output \\
\hline $\mathrm{T}_{\mathrm{GDP}}<\mathrm{T}_{\mathrm{CI}}$ & Decrease in investment efficiency \\
\hline $\mathrm{T}_{\mathrm{IP}}<\mathrm{T}_{\mathrm{RTE}}$ & $\begin{array}{l}\text { Deterioration of the structure of the population } \\
\text { consumption }\end{array}$ \\
\hline $\mathrm{T}_{\mathrm{IP}}<\mathrm{T}_{\mathrm{CI}}$ & Decrease in the vested interests efficiency \\
\hline \multicolumn{2}{|r|}{$2011-2012$} \\
\hline $\mathrm{T}_{\mathrm{GDP}}<\mathrm{T}_{\mathrm{CI}}$ & Decrease in investment efficiency \\
\hline $\mathrm{T}_{\mathrm{IP}}<\mathrm{T}_{\mathrm{VRU}}$ & Decrease in the vested interests efficiency \\
\hline $\mathrm{T}_{\mathrm{IP}}<\mathrm{T}_{\mathrm{RTE}}$ & $\begin{array}{l}\text { Deterioration of the structure of the population } \\
\text { consumption }\end{array}$ \\
\hline $\mathrm{T}_{\mathrm{VIP}}<\mathrm{T}_{\mathrm{IP}}$ & Decrease in the cost of innovative products \\
\hline \multicolumn{2}{|r|}{$2012-2013$} \\
\hline $\mathrm{T}_{\mathrm{GDP}}<\mathrm{T}_{\mathrm{AP}}$ & Decrease in the agricultural production output \\
\hline $\mathrm{T}_{\mathrm{IP}}<\mathrm{T}_{\mathrm{RTE}}$ & $\begin{array}{l}\text { Deterioration of the structure of the population } \\
\text { consumption }\end{array}$ \\
\hline $\mathrm{T}_{\mathrm{CI}}<\mathrm{T}_{\mathrm{NP}}$ & Decrease in investment volume \\
\hline \multicolumn{2}{|r|}{$2013-2014$} \\
\hline $\mathrm{T}_{\mathrm{GDP}}<\mathrm{T}_{\mathrm{IP}}$ & Decrease in the industrial production output \\
\hline $\mathrm{T}_{\mathrm{VIP}}<\mathrm{T}_{\mathrm{IP}}$ & Decrease in the cost of innovative products \\
\hline $\mathrm{T}_{\mathrm{IP}}<\mathrm{T}_{\mathrm{RTE}}$ & $\begin{array}{l}\text { Deterioration of the structure of the population } \\
\text { consumption }\end{array}$ \\
\hline $\mathrm{T}_{\mathrm{CI}}<\mathrm{T}_{\mathrm{NP}}$ & Decrease in investment volume \\
\hline $\mathrm{T}_{\mathrm{NP}}<\mathrm{T}_{\mathrm{UP}}$ & Increase in unemployment \\
\hline \multicolumn{2}{|r|}{$2014-2015$} \\
\hline $\mathrm{T}_{\mathrm{IP}}<\mathrm{T}_{\mathrm{CI}}$ & Decrease in the vested interests efficiency \\
\hline $\mathrm{T}_{\mathrm{VIP}}<\mathrm{T}_{\mathrm{IP}}$ & Decrease in the cost of innovative products \\
\hline \multicolumn{2}{|r|}{$2015-2016$} \\
\hline $\mathrm{T}_{\mathrm{GDP}}<\mathrm{T}_{\mathrm{IP}}$ & Decrease in the industrial production output \\
\hline $\mathrm{T}_{\mathrm{GDP}}<\mathrm{T}_{\mathrm{AP}}$ & Decrease in the agricultural production output \\
\hline $\mathrm{T}_{\mathrm{GDP}}<\mathrm{T}_{\mathrm{CI}}$ & Decrease in investment efficiency \\
\hline $\mathrm{T}_{\mathrm{NP}}<\mathrm{T}_{\mathrm{UP}}$ & Increase in unemployment \\
\hline
\end{tabular}

with low added value in the production structure, the high cost of energy carriers and materials, on the output of basic industries on foreign sales markets.

Taking into account the results of the economic analysis of the regions' development, it would be advisable to develop cooperation between those regions, which have different problems (for sharing experience in those areas that have insufficient development in a given region and to solve them effectively). In practice, interregional connections in Ukraine are born spontaneously depending on the geographical location, that is, cooperation arises between neighbouring regions. This leads to a deepening of socio-economic disparities between regions and affects negatively the country development as a whole. Such a state of things could be improved by introducing a unified national Development Strategy for interregional cooperation to clearly plan priorities, goals, and objectives in this area, and to confidently direct the country towards sustainable development. Unfortunately, now such a strategic document is absent in the regulatory and legal field of Ukraine, and therefore, it is expedient to study the foreign experience of implementing the economic cooperation process between regions and its normative regulations.

\section{Formation of the main principles or the cooperation between regions in Ukraine}

The study of the existing experience from the different countries in the world about the formation and development of economic cooperation between regions tell us about the strength of the interregional integration, expanding cooperation of regions in new market conditions that imply an increase in their economic independence.

Economic cooperation of the regions offers many opportunities for ensuring the progressive and balanced social and economic development of each of the subjects based on establishing strategic, equal, and mutually beneficial relations between them.

The regional level of international relations was widely spread at the end of the 20th century and became one of the characteristic features of the world system relations in the 11th century. Initiated by the federal states, first by the USA and Canada (Börzel, van Hüllen, 2014) in the American continent, Belgium (Chuzhykov, 2008) together with other decentralized states of Europe, the economic ties between the regions in recent decades have entered the practice of many countries. Therefore, among the main tools for implementing the strategy for interregional development, the following can be singled out: the activities of non-state institutions and their assistance in enhancing interregional links; the availability and participation in targeted development programs for territories; the operation of special funds for regional development and support 
of problem areas; the conclusion of contracts between the state, regional agencies development and other stakeholders of interregional development; the activities of institutions engaged in research of the interterritorial and urban planning; participation in various grant programs of international partners together with regional and interregional investors (Čiegis, 2001).

The southern states of the USA and the Canadian province of Quebec were pioneers in the development of economic cooperation between the regions (Ornstein, Stevenson, 1999). Accordingly, their activity to establish relationships with the regions of other states has provoked a response from the partners. As interregional cooperation has become more important for social and economic development, one more area of the subnational authority's activity has been recognized. This led to the understanding that the representation of the regional interests in the international arena is a part of the official responsibilities of the regional leaders and within the framework of a nationwide foreign policy. The activities of governments of some regions and more actively developed interregional ties in this connection have been a stage in the regulation of intra-state relations. This process is understood as the development of the necessary institutions for coordinating regional and national interests, coordinating international activities of the regions, and has served as a model for other subnational units. The Canadian province of Quebec, for instance, was often seen as a model of political and economic cooperation by such Spanish regions as the Basque Country, Catalonia, Flanders, Wallonia. These regions brought their own approaches to solving emerging problems, which led to the emergence of the so-called 'The Catalan Model of Cooperation.'

In the middle of the twentieth century, the world observed the rapid development of public self-awareness in the regions of many countries, which was reflected in the formation of appropriate legal and institutional mechanisms at the domestic and international levels. Thus, various forms of international contacts are supported by regions in practically all democratic states with a federal structure. This phenomenon also becomes characteristic of decentralized countries, such as Spain and the United Kingdom, as well as for unitary and centralized states, for example, Japan or the People's Republic of China (Hänggi, 2006). That is, in regional cooperation they see the way to the development of their economy and the strengthening of international positions as a state with a relatively small volume of Gross Domestic Product (GDP), as well as major world leaders.

At the end of the twentieth century, the interregional activities of the People's Republic of China significantly intensified. Thanks to the reform of the regional administration (called "The Concept of the Purported Regionalization") the subjects of cooperation were granted broader rights, not only in the context of foreign economic activity but also the possibility of establishing special zones and other priority development areas (for trade and investment cooperation).

To develop regional cooperation in modern Europe, there is a fairly developed legal and solid institutional basis. The European Charter and conventions, such as The European Charter of Local Self-Government (Strasbourg, October 1985), The European Outline Convention on Transfrontier Co-operation between Territorial Communities and Authorities (Madrid, May 1980), The European Charter for Regional Languages and the Languages of Minorities (Strasbourg, November 1992), including the part concerning crossborder exchange, The Charter of the Congress of Local and Regional Authorities of Europe (adopted by the Committee of Ministers on January 14, 1994). It should also be mentioned The European Charter of Regional Self-Government, the draft of which was adopted by the Congress of Local and Regional Authorities of Europe of the Council of Europe on June 5, 1997 (The Committee of the Regions, 1999).

Since 1990, the European Union (EU) has begun to provide financial support for interregional cooperation using a number of initiatives, programs, and projects, the common areas of which are listed in Table 1. Support programs such as MEDA (for remote regions of the country that are not EU members); TACIS CBC (covering the border regions of Russia, Ukraine, Belarus, and Moldova); CARDS (program for the Western Balkan countries); LACE (project of the Assembly of European Border Regions, includes advocacy for the implementation of positive practices of cooperation between regions) (Doidge, 2007) and others (Table 1).

Undoubtedly, for the successful implementation of the projects aimed at the cooperation between regions, it is necessary to transfer appropriate powers from central to regional authorities and local governments that are able to provide not only organizational but also financial support to project participants. The principles followed by the countries of Central and Western Europe are also suitable for the implementation in the area of economic cooperation between the regions and the countries of Eastern Europe. Thus, the experience of Romania testifies to the existence of an effective and ramified system of non-state institutions and organizations that contribute to the establishment of interregional links. Such institutions include regional development agencies and chambers of commerce and industry that ensure the effectiveness of links between regions in the following areas: 1) to search for partners in the regions of other countries for implementing joint programs for social and economic development; 2) to participate as a partner in EU programs and joint projects at the international level (Doidge, 2014).

In the countries of Central and Western Europe, the activities of the regional development agencies are 
Table 4

The most common support areas from the EU for the cooperation between regions

\begin{tabular}{|l|l|l|l|}
\hline \multicolumn{1}{|c|}{$\begin{array}{c}\text { Name of the } \\
\text { direction }\end{array}$} & \multicolumn{1}{|c|}{ Purpose } & \multicolumn{1}{c|}{ Participants } & \multicolumn{1}{c|}{ Priority areas of the financing } \\
\hline $\begin{array}{l}\text { Cross-border } \\
\text { cooperation }\end{array}$ & $\begin{array}{l}\text { Development of the joint } \\
\text { local and regional initiatives }\end{array}$ & $\begin{array}{l}\text { Regions of EU member states, } \\
\text { Ukraine }\end{array}$ & $\begin{array}{l}\text { Small and medium business. Tourism and culture. } \\
\text { Protection of the environment. } \\
\text { Transport, information, communication networks } \\
\text { and services. } \\
\text { Joint using the infrastructure in the sphere of culture. } \\
\text { Cooperation of judicial and administrative bodies. }\end{array}$ \\
\hline $\begin{array}{l}\text { Supranational } \\
\text { cooperation }\end{array}$ & $\begin{array}{l}\text { Territorial integration of the } \\
\text { EU countries. }\end{array}$ & $\begin{array}{l}\text { Regions of the Baltic Sea } \\
\text { countries, the Mediterranean } \\
\text { Sea, Central and Eastern Europe }\end{array}$ & $\begin{array}{l}\text { Balanced development in the cities. } \\
\text { Innovative activity. } \\
\text { Protection of the environment. }\end{array}$ \\
\hline $\begin{array}{l}\text { Interregional } \\
\text { cooperation } \\
\text { (INTERREG III) }\end{array}$ & $\begin{array}{l}\text { Experience exchange } \\
\text { between the regional and } \\
\text { local organizations of the EU } \\
\text { countries. }\end{array}$ & $\begin{array}{l}\text { Countries of the EU, Norway, } \\
\text { Switzerland }\end{array}$ & $\begin{array}{l}\text { Innovative activity and knowledge-based economy's } \\
\text { development. } \\
\text { Protection of the environment. }\end{array}$ \\
\hline
\end{tabular}

Source: compiled on the basis of (The European Commission, 2017)

also extraterritorial in nature and are aimed at similar goals. The legislation of the EU does not contain reservations regarding the organizational and legal form of these agencies; therefore, predominantly such are the entities that are formed in accordance with the procedure provided by law on their own initiative or initiative of the government at any level. For instance, in Ireland, Spain, Germany, The United Kingdom, regional development agencies are formed as the state enterprises, in Portugal and France - as the joint-stock companies with a state share in the statutory fund.

The experience of the European countries is also practiced by the participation of the chambers of commerce and industry as the initiators of the creation and functioning of the regional development agencies. The international chambers of commerce are used to establish partnerships for the implementation in different joint programs, so this type of cooperation is an economic cooperation between regions.

Considering the experience of the EU countries in forming the foundations of the interregional economic cooperation, it should be noted that in the context of the decentralization reform in Ukraine and its competitive positioning on the world arena, it is necessary to intensify cooperation of our country's regions not only within the national but also international level. There are certain changes in this direction - cooperation within the framework of the Carpathian Euroregion, the Bug Euroregion, the Danube Transnational Programme, etc. At the same time, the underdevelopment of the institutional infrastructure, the uncertainty in the competence of the regional and local authorities in the field of interregional cooperation, the lack of the strategic programming of the regional development limits the participation of the regions only by separate tactical activities.

\section{Conclusions}

Regional and interregional policies that are almost indivisible operate variously in the economically active countries and are treated differently: as a part of the state overall policy to redistribute income in society, especially in the countries with a target-oriented market economy or as a part of the regional politics.

Obviously, it is impossible to reduce the differences in income and living standards of the population without reducing the differences in the regional economic development levels, clearly manifested in interregional cooperation. As foreign experience shows, regional policy and interregional relations development in any country should differ in the following features: the presence of a conscious and formulated goals vision of the regional and interregional development of the country; the existence of authorities that are responsible for changing the regional territorial proportions; availability of the special tools aimed at raising problem areas in a strategic dimension.

Thus, the analysis of the foreign practice in the formation and implementation of the economic cooperation between regions makes it possible to identify the main prerequisites for this process, on which should be paid attention when implementing this type of interaction in the Ukrainian legal and institutional field (Fig. 1). It will force the formation of integration-type regions that will function to solve common problems or to obtain a certain benefit for the development of their territory.

The current stages of the world economy's spatial changes and the Ukrainian economy are characterized by the implementation of complex, radical transformations of the administrative and territorial structure. Now, for our country, this is connected with the implementation of the decentralization reform components, the essence of which is the direct redistribution of power between the state and 
- economic cooperation between regions should be based exclusively on the common interests and needs of all participants;

- the basis for economic cooperation is the potential advantages of the regions, due to common technologies, similar applications of the corresponding resources, etc. with interconnection and complementarity;

- exchange of experience and achievements in raising the level of social and economic development between regions is seen as the basis for increasing their overall competitiveness;

- it is necessary to transfer the appropriate powers from central authorities to local governments (real, not nominal);

- presence of an extensive and effective system of the non-state institutions in the field of cooperation between regions;

- formulation of the development strategy about the interregional cooperation process for each region;

- creation of an electronic register of the interregional cooperation projects in each region;

- an objective assessment of the economic potential for each region, identifying common interests.

Creation of favourable conditions for realizing the potential of the economic cooperation between regions by the state and regional authorities

Figure 1. Preconditions for the formation and development of the economic cooperation between regions based on the foreign experience

local levels. On the one hand, the signing and entry into force of the Association Agreement between Ukraine and the EU dictate to our country the necessity to activate the European integration reforms, but on the other hand, certain regional differences occur in our country.

Moreover, in the process of a frantic pace of world development and the introduction of scientific and technological progress elements, the approach to understanding the role of economic (productive) resources, which play the main role in the process of carrying out any economic activity, is modified somewhat. Therefore, for the positive foreign practices, introduction in this area and for a qualitative transition of Ukraine from traditional to innovative development of the economy, A. Smith's classic trilogy "land-labour- capital" requires thorough supplementation. Thus, in any country with a modern economy, it is no longer enough simply to accumulate and use traditional types of resources (natural, material, financial, labour), it is important to ensure balanced development of the regions and interregional cooperation in the strategic dimension.

Undoubtedly, the complex task of forming a unified national economic space in Ukraine is strategic, and therefore, its solutions in the context of the world economic, political, and cultural integration are impossible without activation, expansion, and deepening the interregional links, institutionalization of which is a prerequisite for sustainable development of the economy throughout countries, and it can become a topic of further research in this field.

\section{References:}

The State Statistical Service of Ukraine (2018). Regional statistics. Retrieved 15 May 2018 from: http://www.ukrstat.gov.ua/operativ/menu/menu_u/sestr.htm

Timoshin, A. S., Tiazhkorob, I. V., Davydenko, V. M. and Volkov, S. V. (2008). Economic and mathematical support for evaluation of the economic development tendency of the regions in Ukraine. Volodymyr Dahl East-Ukrainian National University Bulletin, 11(241), 45-56.

Börzel, T. A. and van Hüllen V. (2014). One voice, one message, but conflicting goals: cohesiveness and consistency in the European Neighbourhood Policy. Journal of European Public Policy, vol. 21(7), 1033-1049. doi: 10.1080/13501763.2014.912147

Chuzhykov, V. (2008). Modernization of EU regional policy. Economy of Ukraine, 3, 51-58. (in Ukrainian)

Čiegis, R. (2001). Implementation of sustainable development in development strategies of cities and regions, in Efficiency of Public Administration. Kaunas: Technologija, pp. 224-246.

Ornstein, M. D. and Stevenson, H. M. (1999). Politics and Ideology in Canada: Elite and Public Opinion in the Transformation of a Welfare State. Montreal: McGill-Queen's University Press. 
Hänggi, H. (2006). Interregionalism as a multifaceted phenomenon: in search of a typology. Interregionalism and international relations. London: Routledge, pp. 31-62.

The Committee of the Regions (1999). Opinion of the Committee of the Regions on the 'Recommendation of the Congress of Local and Regional Authorities of Europe on a European Charter of Regional Self-Government'. Retrieved 19 Apr 2018 from: https://eur-lex.europa.eu/legal-content/EN/TXT/?uri=CELEX\%3A52000IR0039 Doidge, M. (2007). Joined at the hip: regionalism and Interregionalism. Journal of European integration, 29(2), 229-248. doi: 10.1080/07036330701252474

The European Commission (2017). ESIF-viewer, visualising planned investments using European Structural and Investment Funds. Retrieved 25 Apr 2018 from: http://s3platform.jrc.ec.europa.eu/esif-viewer?p_ auth=Na2f99zE\&p_p_id=generalesifviewertool_WAR_generalesifviewertoolportlet_INSTANCE_ uQEMgwAStPS9\&p_p lifecycle $=1 \& p$ p state $=$ normal\& $\_p$ mode $=$ view\& $p_{p}$ col id $=$ column $-1 \& p$

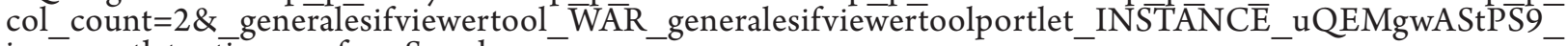
javax.portlet.action=performSearch

Doidge, M. (2014). Interregionalism and the European Union: conceptualizing group-to-group relations. Intersecting Interregionalism: regions, global governance and the EU. Dordrecht: Springer, pp. 37-54. 